\title{
Comparative efficacy of statins, metformin, spironolactone and combined oral contraceptives in reducing testosterone levels in women with polycystic ovary syndrome: a network meta-analysis of randomized clinical trials
}

Hussain H. Almalki ${ }^{1}$, Turki M. Alshibani ${ }^{1}$, Abdullah A. Alhifany ${ }^{1 \dagger}$ and Omar A. Almohammed ${ }^{2 * \dagger}$

\begin{abstract}
Background: Polycystic ovary syndrome (PCOS) is an endocrine disorder affecting about $10 \%$ of women in reproductive age and associated with a variety of hormonal abnormalities, including hyperandrogenemia and infertility, all of which could lead to PCOS. Statins were previously introduced as a therapeutic option for reducing testosterone levels in women with PCOS, either alone or in combination. The aim of this study is to evaluate the effectiveness of different statins alone or in combination with metformin in reducing testosterone levels in women with PCOS.

Methods: Medline, Embase, and clinicaltrials.gov were searched for studies that investigated the efficacy of statins, metformin, spironolactone, or combined oral contraceptives (COCs), individually or in combination, in reducing the testosterone level in patients with PCOS. The search was limited to randomized clinical trials and conducted according to the preferred reporting items for systematic reviews and meta-analyses - extension statement for network meta-analyses (PRISMA-NMA). The quality of included studies was assessed using the Cochrane Collaboration risk of bias (RoB) assessment tool. A frequentist network meta-analysis using random-effects models was used to assess the efficacy in reducing testosterone level and were expressed as odds ratios (OR) and 95\% credible interval $(95 \% \mathrm{Crl})$. All statistical analyses were performed using netmeta Version 1.0 on R statistical package.

\footnotetext{
* Correspondence: oalmohammed@ksu.edu.sa

Abdullah A Alhifany and Omar A Almohammed are senior authors

${ }^{\dagger}$ Abdullah A. Alhifany and Omar A. Almohammed contributed equally to this work.

${ }^{2}$ Department of Clinical Pharmacy, College of Pharmacy, King Saud University, P.O. Box 2457, Riyadh 11451, Saudi Arabia

Full list of author information is available at the end of the article
}

(c) The Author(s). 2020 Open Access This article is licensed under a Creative Commons Attribution 4.0 International License, which permits use, sharing, adaptation, distribution and reproduction in any medium or format, as long as you give appropriate credit to the original author(s) and the source, provide a link to the Creative Commons licence, and indicate if changes were made. The images or other third party material in this article are included in the article's Creative Commons licence, unless indicated otherwise in a credit line to the material. If material is not included in the article's Creative Commons licence and your intended use is not permitted by statutory regulation or exceeds the permitted use, you will need to obtain permission directly from the copyright holder. To view a copy of this licence, visit http://creativecommons.org/licenses/by/4.0/ The Creative Commons Public Domain Dedication waiver (http://creativecommons.org/publicdomain/zero/1.0/) applies to the data made available in this article, unless otherwise stated in a credit line to the data. 
(Continued from previous page)

Result: Nine RCTs involving 613 patients were included. Atorvastatin showed greater reduction in testosterone level compared to COC (MD -2.78, 95\% Crl -3.60, -1.97), spironolactone plus metformin (MD -2.83, 95\% Crl -3.80, -1.87), simvastatin ( $\mathrm{MD}-2.88,95 \% \mathrm{Crl}-3.85,-1.92)$, spironolactone (MD -2.90, 95\% Cl -3.77, -2.02), simvastatin plus metformin ( $\mathrm{MD}-2.93,95 \% \mathrm{Crl}-3.79,-2.06)$, metformin (MD -2.97, 95\% Crl -3.69, -2.25), lifestyle modification (MD $-3.02,95 \% \mathrm{Crl}-3.87,-2.18)$, and placebo (MD -3.04, 95\% Crl -3.56, -2.53).

Conclusion: Atorvastatin was found to be more effective than the other management strategies in reducing the total testosterone level for patients with PCOS. Future studies should focus on the optimal dose.

Keywords: Statins, Metformin, Spironolactone, Contraceptives, PCOS, Testosterone

\section{Introduction}

Polycystic ovary syndrome (PCOS) is an endocrine disorder affecting about $10 \%$ of women in reproductive age and associated with a variety of hormonal abnormalities such as menstrual irregularity, insulin resistance, clinical hyperandrogenism or hyperandrogenemia, and infertility [1], all of which could lead to PCOS, despite their different features [2], The reduction in testosterone level is one of the most common outcomes reported in clinical trials [19], and it is frequently used by clinicians to assess the progress of patient's condition.

The use of statins has been recently introduced as a therapeutic option for PCOS, either alone or in combination with metformin or combined oral contraceptives (COCs). To date, the guidelines recommend lifestyle modifications and weight reduction for all patients with PCOS along with COCs, metformin, or spironolactone to be individualized based on the patients' presentation. However, the role of statins and its importance for patients with PCOS remains controversial [10].

COCs are the first-line therapies for managing menstrual irregularities in women with PCOS [4]. COCs exert their effect via reducing the level of androgen, which consequently lead to regulating menses [4]. For those intolerant to COCs, several trials confirmed the efficacy of metformin in reducing the androgen levels $[3,4,6,11]$. Spironolactone inhibits the synthesis of steroids; therefore, it has been used in the treatment of PCOS to reduce high androgen-induced features, such as hirsutism and menstrual irregularity [9]. Simvastatin and atorvastatin are indicated for hypercholesterolemia [12] and have shown comparable efficacy to other antiandrogen agents in decreasing the level of androgen in women with PCOS [13].

In the absence of studies demonstrating the preferred therapy for patients with PCOS who present with high androgen-induced features, the current study was conducted to evaluate the effectiveness of different statins alone or in combination with metformin in treating patients with PCOS.

\section{Methods}

A systematic review was conducted using Medline, Embase, and clinicaltrials.gov for studies using COCs, statins, spironolactone, and metformin for treatment of patients with PCOS. The patients, intervention, comparator, outcome, and study design (PICOS) strategy was used to identify relevant terms (Table 1 ), and search terms included polycystic ovary syndrome and antiandrogen. The search was limited to peer-reviewed randomized clinical trials (RCTs) that were conducted in humans and published in English. Studies were included if they evaluated the effect of medications on the change in total testosterone level as their efficacy outcome.

Data were extracted from the included studies by two independent investigators (HHA and TMA), and verified by a third investigator (AAA). For each study, the reduction in total testosterone reported as mean difference (MD) and standard deviation (SD) were extracted from studies as our primary outcome. If MD and SD were not provided in the studies, they were calculated using the equations in Table 2 [14]. A frequentist network meta-analysis using randomeffects models was used to assess the efficacy in reducing testosterone levels and were expressed as odds ratio (OR) and $95 \%$ credible interval $(95 \% \mathrm{Crl})$. All statistical analyses and inconsistency tests were performed using netmeta Version 1.0 on $\mathrm{R}$ statistical package [15]. The study was conducted according to the preferred reporting items for systematic reviews and meta-analyses for network metaanalyses (PRISMA-NMA) [16]. The risk of bias assessment was conducted for included studies using the Cochrane Collaboration risk of bias (RoB) assessment tool, and the Review Manager version 5.3 (Rev-man, the Nordic Cochrane Centre, Copenhagen 2014) were used to generate the RoB tables.

Table 1 PICOS framework

\begin{tabular}{ll}
\hline Population & Women with PCOS \\
Intervention & Statins \\
Comparator & $\begin{array}{l}\text { Combined oral contraceptives (COC), metformin, } \\
\text { placebo, lifestyle modification, or spironolactone }\end{array}$ \\
Outcome & $\begin{array}{l}\text { Reduction in the blood level of testosterone } \\
\text { Study design }\end{array}$ \\
& $\begin{array}{l}\text { Published or unpublished randomized } \\
\text { controlled trials }\end{array}$ \\
\hline
\end{tabular}


Table 2 Equations to calculate MD, SD, and correlation coefficient

\begin{tabular}{ll}
\hline Equation 1: & Mean Change $(M D)=M 2-M 1$ \\
Equation 2: & $S D$ Change $=\sqrt{S D 1^{2}+S D 2^{2}-(2 \times \text { Corr } \times S D 1 \times S D 2)}$ \\
Equation 3: & Corr $=\frac{\left(S D 1^{2}+S D 2^{2}-S D \text { change }^{2}\right)}{(2 \times S D 1 \times S D 2)}$
\end{tabular}

M1: Mean level of testosterone at baseline; M2: Mean level of testosterone after treatment, SD1: Standard deviation of testosterone level at baseline; SD2: standard deviation of testosterone level after treatment; Corr: correlation coefficient, which is the value that describes how similar the baseline and final measurements were across participant [14]

Equation 1 was used to calculate the mean difference of testosterone between baseline and after treatment, Equation 2 was used to impute a standard deviation of the change from baseline, and Equation 3: was used to calculate the correlation coefficient [14]. Corr was calculated using the SD1, SD2, and SD Change; since the SD change was not reported by some of the included studies, it was extrapolated from other similar studies $[5,8]$

\section{Results}

A total of 281 articles were identified in the systematic search, and among these 9 articles were included in the network meta-analysis. The flowchart in Fig. 1 illustrates the process of including and excluding articles for this systematic review and network meta-analysis. The included studies were described in Table 3 [1-9].

The interventions in the included studies were COCs, atorvastatin, simvastatin, spironolactone, simvastatin plus metformin (SmivMet), metformin plus spironolactone (MetSpiro), metformin alone, and placebo. There was a direct comparison between atorvastatin and placebo and between simvastatin and metformin; however, no trials made a direct comparison between statins and other therapies. Therefore, a network meta-analysis deemed necessary to provide an indirect comparison between the interventions (Fig. 2). The summary of the results from the inconsistency test and the quality assessment of the included studies and risk of bias table were provided respectively in Table S1 and Figures S1 and S2 of the supplementary material.

\section{Comparative efficacy of interventions in PCOS}

Metformin was the only management strategy that was evaluated directly to most of the other strategies. When compared to metformin, the pairwise comparison showed no significant difference in reducing the testosterone level for all management strategies. The results from the pairwise meta-analysis are presented in Table 4 above the leading diagonal.

In the network meta-analysis, atorvastatin showed greater reduction in testosterone level compared to COC (MD -2.78, 95\% CrI -3.60, - 1.97), spironolactone plus metformin (MD $-2.83,95 \% \mathrm{CrI}-3.80,-1.87)$, simvastatin (MD $-2.88,95 \% \mathrm{CrI}-3.85,-1.92)$, spironolactone (MD $-2.90,95 \% \mathrm{CI}-3.77,-2.02)$, simvastatin plus metformin (MD $-2.93,95 \% \mathrm{CrI}-3.79,-2.06)$, metformin (MD -2.97, 95\%CrI -3.69, -2.25), lifestyle modification (MD -3.02, 95\% CrI -3.87, -2.18), and placebo (MD

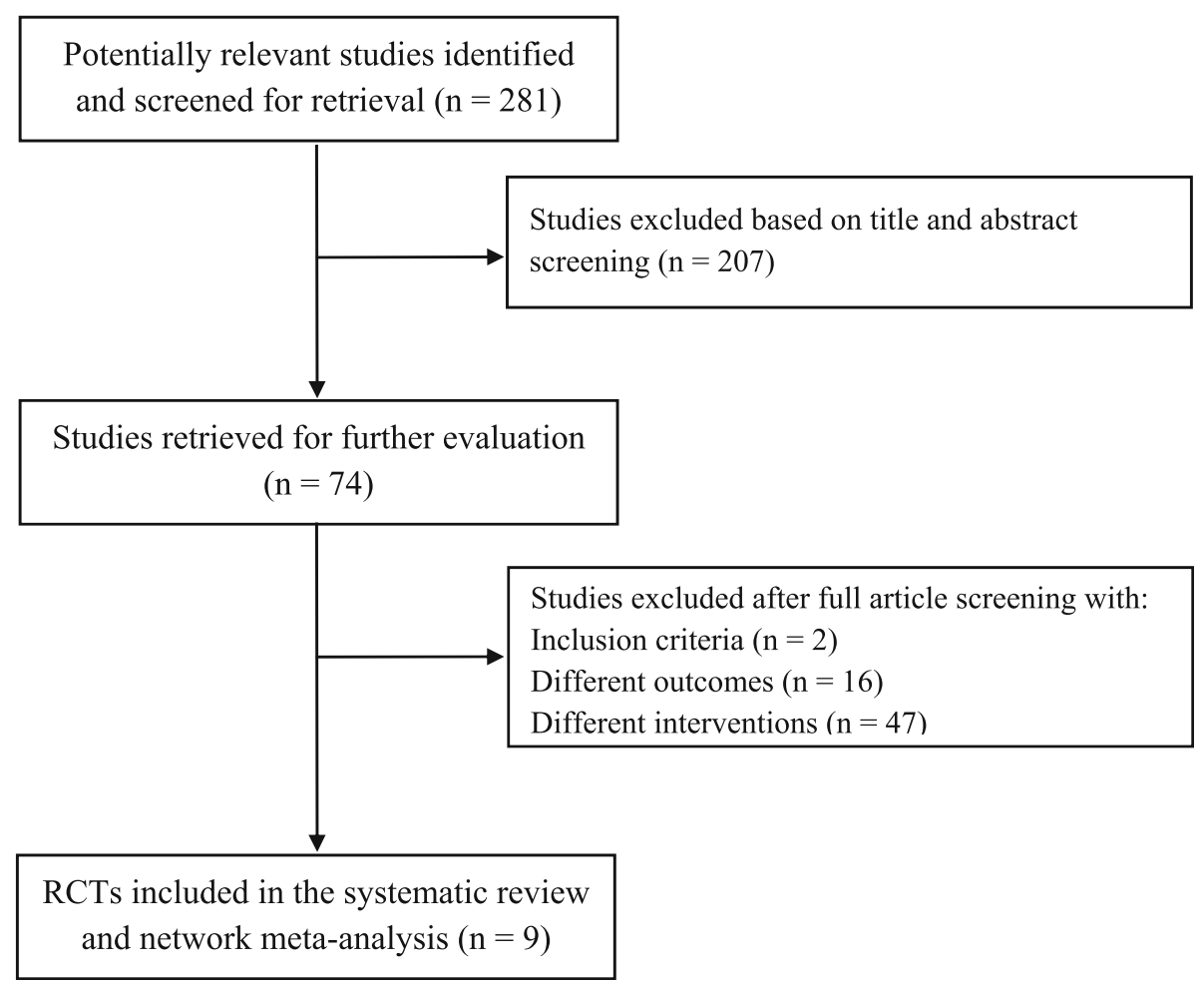

Fig. 1 Flow diagram for study selection 
Table 3 Studies that were included in the network meta-analysis

\begin{tabular}{|c|c|c|c|c|c|c|c|c|c|}
\hline Author & Year & Country & $\begin{array}{l}\text { Follow-up } \\
\text { period }\end{array}$ & Design for the study & $n$ & $\begin{array}{l}\text { Age } \\
\text { (yr.) }\end{array}$ & $\begin{array}{l}\mathrm{BMI}(\mathrm{Kg} / \\
\left.\mathrm{m}^{2}\right)\end{array}$ & Intervention & Control \\
\hline $\begin{array}{l}\text { Ganie et al. } \\
\text { [3] }\end{array}$ & 2004 & India & 6 months & $\begin{array}{l}\text { Randomized open- } \\
\text { labelled clinical trial }\end{array}$ & 69 & $\begin{array}{l}17.6- \\
28.5\end{array}$ & $20.9-32.1$ & $\begin{array}{l}\text { Spironolactone } \\
(n=34)\end{array}$ & $\operatorname{Metformin}(n=35)$ \\
\hline $\begin{array}{l}\text { Hoeger et al. } \\
\text { [4] }\end{array}$ & 2008 & USA & 24 weeks & $\begin{array}{l}\text { Randomized clinical } \\
\text { trial }\end{array}$ & 43 & $\begin{array}{l}13.7- \\
17.7\end{array}$ & $27.8-46.0$ & $\begin{array}{l}\text { Metformin }(n=10) \text {, } \\
\text { COC }(n=11) \text {, or } \\
\text { lifestyle modification } \\
(n=11)\end{array}$ & Placebo $(n=11)$ \\
\hline $\begin{array}{l}\text { Sathyapalan } \\
\text { et al. [5] }\end{array}$ & 2009 & UK & 12 weeks & $\begin{array}{l}\text { Randomized double- } \\
\text { blind clinical trial }\end{array}$ & 37 & $\begin{array}{l}26.3- \\
29.1\end{array}$ & $31.8-35.4$ & Atorvastatin $(n=19)$ & Placebo $(n=18)$ \\
\hline $\begin{array}{l}\text { Kazerooni } \\
\text { et al. [1] }\end{array}$ & 2010 & Iran & 12 weeks & $\begin{array}{l}\text { Randomized double- } \\
\text { blind clinical trial }\end{array}$ & 84 & $\begin{array}{l}19.1- \\
30.7\end{array}$ & $27.3-30.3$ & $\begin{array}{l}\text { Metformin + Simvastatin } \\
(n=42)\end{array}$ & $\begin{array}{l}\text { Metformin + Placebo } \\
(n=42)\end{array}$ \\
\hline $\begin{array}{l}\text { Romualdi } \\
\text { et al. [6]. }\end{array}$ & 2010 & Italy & 6 months & $\begin{array}{l}\text { Randomized double- } \\
\text { blind clinical trial }\end{array}$ & 28 & $\begin{array}{l}20.3- \\
29.8\end{array}$ & $18.4-26.2$ & Metformin $(n=15)$ & Placebo $(n=13)$ \\
\hline $\begin{array}{l}\text { Teede et } \\
\text { al. [7] }\end{array}$ & 2010 & Australia & 6 months & $\begin{array}{l}\text { Randomized clinical } \\
\text { trial }\end{array}$ & 66 & $\begin{array}{l}26.8- \\
40.2\end{array}$ & $34.3-37.8$ & Metformin $(n=36)$ & $\operatorname{cocs}(n=30)$ \\
\hline $\begin{array}{l}\text { Raja-Khan } \\
\text { et al. [8] }\end{array}$ & 2011 & USA & 6 weeks & $\begin{array}{l}\text { Randomized double- } \\
\text { blind clinical trial }\end{array}$ & 20 & $\begin{array}{l}23.6- \\
38.1\end{array}$ & $25.6-51.9$ & Atorvastatin $(n=9)$ & Placebo $(n=11)$ \\
\hline $\begin{array}{l}\text { Banaszewska } \\
\text { et al. [2] }\end{array}$ & 2011 & Poland & 6 months & $\begin{array}{l}\text { Randomized open- } \\
\text { labelled clinical trial }\end{array}$ & 97 & $\begin{array}{l}24.7- \\
26.9\end{array}$ & $22.9-25.6$ & $\begin{array}{l}\text { Simvastatin + Metformin } \\
(n=36)\end{array}$ & $\begin{array}{l}\text { Simvastatin }(n=28) \text { or } \\
\text { Metformin }(n=33)\end{array}$ \\
\hline $\begin{array}{l}\text { Ganie et } \\
\text { al. [9] }\end{array}$ & 2013 & India & 6 months & $\begin{array}{l}\text { Randomized open- } \\
\text { labelled clinical trial }\end{array}$ & 169 & $\begin{array}{l}17.2- \\
28.8\end{array}$ & $20.0-30.1$ & $\begin{array}{l}\text { Spironolactone }+ \\
\text { Metformin }(n=62)\end{array}$ & $\begin{array}{l}\text { Spironolactone }(n=51) \\
\text { or Metformin }(n=56)\end{array}$ \\
\hline
\end{tabular}

$-3.04,95 \% \mathrm{CrI}-3.56,-2.53)$. The results from network meta-analysis is presented in Table 4 below the leading diagonal.

\section{Discussion}

The study evaluated the effect of atorvastatin in reducing testosterone levels in women with PCOS utilizing the network-meta analysis technique to provide a direct and indirect comparison of all interventions used to treat PCOS, with the goal of providing a comprehensive picture of statins alone or as add-on therapy with metformin or COC for clinicians and patients. The study found that atorvastatin provided a greater reduction in testosterone levels in patients with PCOS when compared to $\mathrm{COC}$, spironolactone plus metformin, simvastatin, spironolactone, simvastatin plus metformin, metformin, lifestyle modification, and placebo, respectively.

The pros and cons of atorvastatin use in improving PCOS symptoms have been addressed in the literature [17-19]. It has been shown that using atorvastatin for a duration of more than 12 weeks had substantially improved PCOS symptoms [17], yet, it impairs insulin sensitivity [18]. However, to our knowledge, this is the first study to compare between atorvastatin and all interventions in terms of reducing the testosterone level in patients with PCOS. Initially, we have combined atorvastatin and simvastatin as one group (statins); however, this led to a significant inconsistency ( $p$-value $<0.05)$. Hence, we have separated the atorvastatin and the simvastatin into two groups.
COC is the first line of treatment in patients with PCOS as it provides a great remission for PCOS symptoms [10]; however, it prevents patients from conceiving, if they want to be. Metformin alone, as the first line of treatment, allows patients to conceive, but it is inferior in terms of resolving PCOS symptoms [10]. From the current study, atorvastatin was found to be better in reducing testosterone levels, which would resolve PCOS symptoms without interfering with the ability to conceive.

The main limitations of our network meta-analysis are the significant heterogeneity among the included studies. The nine studies that were included in the NMA used different diagnostic criteria for PCOS, leading to different types of participants were included. Also, different

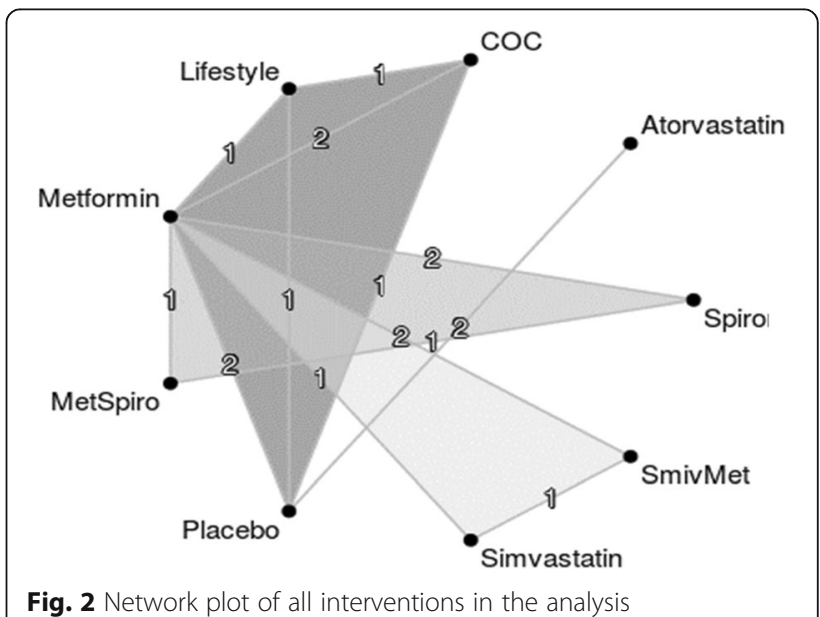


Table 4 Network meta-analysis and pairwise meta-analysis of all interventions (Random Effect)

\begin{tabular}{|c|c|c|c|c|c|c|c|c|}
\hline Atorvastatin & & & & & & & & $\begin{array}{l}-3.04[-3.56 ; \\
-2.53]\end{array}$ \\
\hline $\begin{array}{l}-2.78[-3.60 \\
-1.97]\end{array}$ & $\mathrm{COC}$ & & & & & $\begin{array}{l}-0.18[-0.70 \\
0.34]\end{array}$ & $\begin{array}{l}-0.31[-1.08 \\
0.46]\end{array}$ & $\begin{array}{l}-0.35[-1.16 ; \\
0.46]\end{array}$ \\
\hline $\begin{array}{l}-2.83[-3.80 \\
-1.87]\end{array}$ & $\begin{array}{l}-0.05[-0.87 \\
0.78]\end{array}$ & MetSpiro & & $\begin{array}{l}-0.09[-0.80 \\
0.62]\end{array}$ & & $\begin{array}{l}-0.11[-0.80 \\
0.58]\end{array}$ & & . \\
\hline $\begin{array}{l}-2.88[-3.85 ; \\
-1.92]\end{array}$ & $\begin{array}{l}-0.10[-0.92 ; \\
0.72]\end{array}$ & $\begin{array}{l}-0.05[-0.96 ; \\
0.86]\end{array}$ & Simvastatin & & $\begin{array}{l}-0.06[-0.74 \\
0.62]\end{array}$ & $\begin{array}{l}-0.07[-0.75 \\
0.61]\end{array}$ & . & \\
\hline $\begin{array}{l}-2.90[-3.77 ;- \\
2.02]\end{array}$ & $\begin{array}{l}-0.11[-0.83 ; \\
0.61]\end{array}$ & $\begin{array}{l}-0.06[-0.72 ; \\
0.59]\end{array}$ & $\begin{array}{l}-0.01[-0.83 ; \\
0.80]\end{array}$ & Spironolactone & & $\begin{array}{l}-0.07[-0.58 ; \\
0.43]\end{array}$ & & . \\
\hline $\begin{array}{l}-2.93[-3.79 \\
-2.06]\end{array}$ & $\begin{array}{l}-0.14[-0.85 \\
0.56]\end{array}$ & $\begin{array}{l}-0.09[-0.90 ; \\
0.72]\end{array}$ & $\begin{array}{l}-0.04[-0.68 ; \\
0.60]\end{array}$ & $\begin{array}{l}-0.03[-0.73 ; \\
0.67]\end{array}$ & SimvMet & $\begin{array}{l}-0.04[-0.53 ; \\
0.44]\end{array}$ & . & \\
\hline $\begin{array}{l}-2.97[-3.69 ;- \\
2.25]\end{array}$ & $\begin{array}{l}-0.19[-0.70 ; \\
0.33]\end{array}$ & $\begin{array}{l}-0.14[-0.78 ; \\
0.51]\end{array}$ & $\begin{array}{l}-0.09[-0.73 ; \\
0.55]\end{array}$ & $\begin{array}{l}-0.07[-0.58 \\
0.43]\end{array}$ & $\begin{array}{l}-0.04[-0.53 ; \\
0.44]\end{array}$ & Metformin & $\begin{array}{l}-0.02[-0.70 ; \\
0.67]\end{array}$ & $\begin{array}{l}-0.05[-0.56 ; \\
0.47]\end{array}$ \\
\hline $\begin{array}{l}-3.02[-3.87 ; \\
-2.18]\end{array}$ & $\begin{array}{l}-0.24[-0.93 ; \\
0.45]\end{array}$ & $\begin{array}{l}-0.19[-1.09 ; \\
0.71]\end{array}$ & $\begin{array}{l}-0.14[-1.03 ; \\
0.75]\end{array}$ & $\begin{array}{l}-0.13[-0.93 ; \\
0.67]\end{array}$ & $\begin{array}{l}-0.10[-0.89 \\
0.69]\end{array}$ & $\begin{array}{l}-0.05[-0.68 ; \\
0.57]\end{array}$ & Lifestyle & $\begin{array}{l}-0.03[-0.76 \\
0.70]\end{array}$ \\
\hline $\begin{array}{l}-3.04[-3.56 \\
-2.53]\end{array}$ & $\begin{array}{l}-0.26[-0.89 \\
0.38]\end{array}$ & $\begin{array}{l}-0.21[-1.03 ; \\
0.61]\end{array}$ & $\begin{array}{l}-0.16[-0.97 \\
0.65]\end{array}$ & $\begin{array}{l}-0.15[-0.86 \\
0.56]\end{array}$ & $\begin{array}{l}-0.12[-0.81 \\
0.58]\end{array}$ & $\begin{array}{l}-0.07[-0.57 ; \\
0.43]\end{array}$ & $\begin{array}{l}-0.02[-0.68 \\
0.65]\end{array}$ & Placebo \\
\hline
\end{tabular}

Treatments were ranked from best to least along the leading diagonal from the random-effect analysis. Above the leading diagonal are estimates from pairwise meta-analyses and below are estimates from the network meta-analyses. Data presented are mean difference (MD) with $95 \%$ confidence interval ( $95 \% \mathrm{Cl}$ ) or $95 \%$ credible interval $(95 \% \mathrm{Crl})$ for the pairwise meta-analysis or network meta-analysis, respectively. MD below 0 indicate higher efficacy in reducing testosterone level. Bold values indicate comparisons that are statistically significant

Abbreviations: COC combined oral contraceptive, MetSpiro Spironolactone plus Metformin, SimvMet Metformin plus Simvastatin

types and doses of statins were used, which could have affected the outcome of the study. The baseline characteristics for the participants in the trials differed in terms of age, BMI, and ethnicity, which may have affected the results. Moreover, the design for the studies, drug dosage, and follow-up duration, thus it may have affected the results. Finally, in the current study, we only evaluated the interventions based on the change in the testosterone level, which might limit the utilization of the results to patients with a high level of testosterone only.

\section{Conclusion}

The findings from the current study supports the use of atorvastatin over $\mathrm{COC}$, spironolactone plus metformin, simvastatin, spironolactone, simvastatin plus metformin, metformin, lifestyle modification, and placebo, as it was associated with the greatest reduction in testosterone levels; knowing that the anaylyses were conducted including the beset available evidence at the time of the study. Therefore, atorvastatin should be recommended, with caution, in PCOS patients who present with a high level of testosterone. Larger randomized clinical trials are needed to identify atorvastatin dose with the best effect in patients with PCOS.

\section{Supplementary information}

Supplementary information accompanies this paper at https://doi.org/10. 1186/s12905-020-00919-5.

Additional file 1 Table S1. Direct and indirect comparison from the network meta-analysis and the inconsistency test results
Additional file $\mathbf{2}$ Figure $\mathbf{S 1}$. Summary for the risk of bias assessment Additional file $\mathbf{3}$ Figure $\mathbf{S 2}$. Risk of bias table of all included studies.

\section{Abbreviations}

PCOS: Polycystic ovary syndrome; COCs: Combined oral contraceptives; RoB: Risk of bias; OR: Odds ratios; 95\%Crl: 95\% Credible interval; MD: Mean difference; SD: Standard deviation; Corr: Correlation coefficient; SmivMet: Simvastatin plus metformin; MetSpiro: Metformin plus spironolactone

\section{Acknowledgments}

The authors would like to extend their appreciation to King Saud University for funding this work through the Researcher Supporting Project number (RSP-2019/77), King Saud University, Riyadh, Saudi Arabia.

\section{Authors' contributions}

HHA and TMA extracted the data and were major contributors in writing the manuscript. AAA designed the study, reviewed and analyzed the extracted data, and participated in writing the manuscript. OAA reviewed the analysis and was a major contributor in writing the manuscript. All authors read and approved the final manuscript.

\section{Funding}

The author (OAA) received a fund from the Researcher Supporting Project number (RSP-2019/77), King Saud University, Riyadh, Saudi Arabia, to support the publication of this article. The funding agency had no role in designing the study, conducting the analysis, interpreting the data or writing the manuscript.

Availability of data and materials

All data generated or analyzed during this study are included in this published article [and its supplementary information files].

Ethics approval and consent to participate Not applicable.

Consent for publication Not applicable. 


\section{Competing interests}

The authors declare that they have no competing interests.

\section{Author details}

'Department of Clinical Pharmacy, College of Pharmacy, Umm Al-Qura University, 13578 Taif Rd, Makkah 21955, Saudi Arabia. ${ }^{2}$ Department of Clinical Pharmacy, College of Pharmacy, King Saud University, P.O. Box 2457, Riyadh 11451, Saudi Arabia.

Received: 25 November 2019 Accepted: 6 March 2020

Published online: 05 April 2020

\section{References}

1. Kazerooni T, Shojaei-Baghini A, Dehbashi S, Asadi N, Ghaffarpasand F, Kazerooni Y. Effects of metformin plus simvastatin on polycystic ovary syndrome: a prospective, randomized, double-blind, placebo-controlled study. Fertil Steril. 2010;94:2208-13. https://doi.org/10.1016/j.fertnstert.2009. 11.045 .

2. Banaszewska B, Pawelczyk L, Spaczynski RZ, Duleba AJ. Effects of simvastatin and metformin on polycystic ovary syndrome after six months of treatment. J Clin Endocrinol Metab. 2011;96:3493-501. https://doi.org/10.1210/jc.20110501.

3. Ganie MA, Khurana ML, Eunice M, Gulati M, Dwivedi SN, Ammini AC. Comparison of efficacy of spironolactone with metformin in the management of polycystic ovary syndrome: an open-labeled study. J Clin Endocrinol Metab. 2004;89:2756-62. https://doi.org/10.1210/jc.2003-031780.

4. Hoeger K, Davidson K, Kochman L, Cherry T, Kopin L, Guzick DS. The impact of metformin, oral contraceptives, and lifestyle modification on polycystic ovary syndrome in obese adolescent women in two randomized, placebocontrolled clinical trials. J Clin Endocrinol Metab. 2008;93:4299-306. https:// doi.org/10.1210/jc.2008-0461.

5. Sathyapalan T, Kilpatrick ES, Coady A-M, Atkin SL. The effect of atorvastatin in patients with polycystic ovary syndrome: a randomized double-blind placebo-controlled study. J Clin Endocrinol Metab. 2009;94:103-8. https:// doi.org/10.1210/jc.2008-1750.

6. Romualdi D, Giuliani M, Cristello F, Fulghesu AM, Selvaggi L, Lanzone A, et al. Metformin effects on ovarian ultrasound appearance and steroidogenic function in normal-weight normoinsulinemic women with polycystic ovary syndrome: a randomized double-blind placebo-controlled clinical trial. Fertil Steril. 2010;93:2303-10. https://doi.org/10.1016/j.fertnstert. 2009.01.114.

7. Teede HJ, Meyer C, Hutchison SK, Zoungas S, McGrath BP, Moran L. Endothelial function and insulin resistance in polycystic ovary syndrome: the effects of medical therapy. Fertil Steril. 2010;93:184-91. https://doi.org/ 10.1016/j.fertnstert.2008.09.034

8. Raja-Khan N, Kunselman AR, Hogeman CS, Stetter CM, Demers LM, Legro RS. Effects of atorvastatin on vascular function, inflammation, and androgens in women with polycystic ovary syndrome: a double-blind randomized, placebo-controlled trial. Fertil Steril. 2011;95:1849-52. https:// doi.org/10.1016/j.fertnstert.2010.11.040.

9. Ganie MA, Khurana ML, Nisar S, Ahmed Shah P, Amin Shah Z, Kulshrestha B, et al. Improved efficacy of low-dose spironolactone and metformin combination than either drug alone in the management of women with polycystic ovary syndrome (PCOS): a six-month, open-label randomized study. J Clin Endocrinol Metab. 2013;98:3599-607. https://doi.org/10.1210/jc. 2013-1040.

10. Legro RS, Arslanian SA, Ehrmann DA, Hoeger KM, Murad MH, Pasquali R, et al. Diagnosis and treatment of polycystic ovary syndrome: an endocrine society clinical practice guideline. J Clin Endocrinol Metab. 2013;98:4565-92. https://doi.org/10.1210/j.2013-2350.

11. Kazerooni T, Ghaffarpasand F, Kazerooni Y, Kazerooni M, Setoodeh S. Shortterm metformin treatment for clomiphene citrate-resistant women with polycystic ovary syndrome. Int J Gynaecol Obstet. 2009;107:50-3. https://doi. org/10.1016/j.ijgo.2009.04.022.

12. Thabit A, Alhifany A, Alsheikh R, Namnqani S, Al-Mohammadi A, Elmorsy S, et al. Effect of simvastatin and atorvastatin on serum vitamin $D$ and bone mineral density in hypercholesterolemic patients: a cross-sectional study. J Osteoporos. 2014;2014:9. https://doi.org/10.1155/2014/468397.

13. Banaszewska B, Pawelczyk L, Spaczynski RZ, Duleba AJ. Comparison of simvastatin and metformin in treatment of polycystic ovary syndrome: prospective randomized trial. J Clin Endocrinol Metab. 2009;94:4938-45. https://doi.org/10.1210/jc.2009-1674.

14. Higgins JPT, Green S. Cochrane handbook for systematic reviews of interventions. London: The Cochrane Collaboration; 2011.

15. Owen RK, Bradbury N, Xin Y, Cooper N, Sutton A. Metalnsight: an interactive web-based tool for analyzing, interrogating, and visualizing network metaanalyses using R-shiny and netmeta. Res Synth Methods. 2019;10:569-81. https://doi.org/10.1002/jrsm.1373.

16. Hutton B, Salanti G, Caldwell DM, Chaimani A, Schmid CH, Cameron C, et al. The PRISMA extension statement for reporting of systematic reviews incorporating network meta-analyses of health care interventions: checklist and explanations. Ann Intern Med. 2015;162:777-84. https://doi.org/10.7326/ m14-2385.

17. Yang S, Gu Y-Y, Jing F, Yu C-X, Guan Q-B. The effect of statins on levels of dehydroepiandrosterone (DHEA) in women with polycystic ovary syndrome: a systematic review and meta-analysis. Med Sci Monit. 2019;25:590-7. https://doi.org/10.12659/MSM.914128.

18. Puurunen J, Piltonen T, Puukka K, Ruokonen A, Savolainen MJ, Bloigu R, et al. Statin therapy worsens insulin sensitivity in women with polycystic ovary syndrome (PCOS): a prospective, randomized, double-blind, placebocontrolled study. J Clin Endocrinol Metab. 2013;98:4798-807. https://doi.org/ 10.1210/jc.2013-2674.

19. Cassidy-Vu L, Joe E, Kirk JK. Role of statin drugs for polycystic ovary syndrome. J Family Reprod Health. 2016;10:165-75.

\section{Publisher's Note}

Springer Nature remains neutral with regard to jurisdictional claims in published maps and institutional affiliations.

\section{Ready to submit your research? Choose BMC and benefit from:}

- fast, convenient online submission

- thorough peer review by experienced researchers in your field

- rapid publication on acceptance

- support for research data, including large and complex data types

- gold Open Access which fosters wider collaboration and increased citations

- maximum visibility for your research: over $100 \mathrm{M}$ website views per year

At BMC, research is always in progress.

Learn more biomedcentral.com/submissions 